\title{
Seasonal variations in abundance and diversity of insect pollinator in forest ecosystems of Southern Punjab Pakistan
}

\author{
Muhammad Amjad Bashir ${ }^{1}$, Shafqat Saeed ${ }^{2 *}$, Asif Sajjad ${ }^{2}$ and Muddasar \\ $\mathrm{Ali}^{2}$ \\ 1College of Agriculture DG Khan University of Agriculture Faisalabad Pakistan \\ 2Faculty of Agriculture Baha-Ud- Din Zakaryia University Multan \\ *Corresponding author email: bumblebeepak@gmail.com \\ Citation \\ Muhammad Amjad Bashir, Shafqat Saeed, Asif Sajjad and Muddasar Ali. Seasonal variations in abundance and \\ diversity of insect pollinator in forest ecosystems of Southern Punjab Pakistan. Pure and Applied Biology. Vol. 4, \\ Issue 3, 2015, pp 441-452. http://dx.doi.org/10.19045/bspab.2015.43021
}

Received: $15 / 06 / 2015$

Revised: 20/08/2015

Accepted: $25 / 08 / 2015$

\section{Abstract}

Seasonal Variation of pollinators in relation to abundance and diversity was studied for one year in forest ecosystems of Perowal (Central Agriculture Zone, southern Punjab, Pakistan) where average maximum and minimum temperature ranges from 19.4 to $43.3^{\circ} \mathrm{C}$ and $5^{\circ} \mathrm{C}$ to $31.3^{\circ} \mathrm{C}$, respectively. Pollinators from two insect orders (Diptera and Hymenoptera) were satisfied. Results showed that flies and bees remained active throughout the year while the activity of the wasps stopped during months of December-February (winter) when temperature was dropped below 20 ${ }^{\circ} \mathrm{C}$. Forty two flies species belonging to ten different families were observed. Among flies Euphumosiasp, E. aeneus, and Musca domestica were the most abundant overall. The peak abundance and richness of bees was observed in spring and summer respectively. Similarly the community of bees was composed of 68 different species which were representing from five families. Among bees, Apis dosata, Apis floreia and Halictus sp. were the most abundant overall. The peak abundance and richness of bees was observed in summer. While, wasps community was composed of 57 different species which were representing from nine families. Among wasps, Delta dimidiatipenne, Delta esuriensesuriens and Vespaorientalis were the most abundant overall. The peak abundance and richness of wasps was observed in spring and autumn while zero population in winter.

Keyword: Perowal; Flies \& Bees ; Wasps; Diptera and Hymenoptera.

\section{Introduction}

There is a tremendous diversity of pollination systems, and hence, great differences lie in the degree of specialization for pollinators among plants or for flowers among animals [1]. Pollination systems can be classified into types of plant species with functionally similar flowers and similar pollinator compositions (guilds). These types are called pollination syndromes [2]. Furthermore, pollinators often fall into functional groups where visitors likely share attributes of behavior, and these functional groups are predicted on the basis of pollination syndrome traits (i.e., flower color, fragrance, reward, and morphology) [3]. 
Meaningful ecological studies on insect communities require sampling protocols that take into consideration temporal fluctuations in abundance and species composition to avoid misleading results. The effects of sampling effort or seasonality on ecological patterns are only documented for a few insect groups. Sampling effort accounted for a large proportion of the variance in alpha diversity in two of three guilds of a phyto-phagous insect community on Brassicaceae [4] Furthermore; seasonal patterns depend on the level of specialization and the feeding habits of pollinators [5]. Bees (Hymenoptera, Apiforms) with their high habitat requirements have recently been used as indicators of biodiversity or landscape structure in ecological studies [6-8].The Principal flower visiting insects are Hymenopterans and Dipterous because of the following reasons. Approximately $73 \%$ of the worlds cultivated crops are depended for pollination by some variety of bees, $19 \%$ by flies, $6.5 \%$ by bats, $5 \%$ by wasps, $5 \%$ by beetles, $4 \%$ by birds, and $4 \%$ by butterflies and moths. Of the hundred major crops that make up a vast majority of the world's food source, at least $80 \%$ are pollinated by bees. The 25,000 different species of bees differ significantly in size and habit requirements, and deviate consequently in the plants they visit and fertilize. Though bees form the most important group of pollinators (Fact Sheet: Pollinator Diversity, 2004), after this the flies are the second most important group of pollinators because flies probably were among the first important angiosperm pollinators and may have, as such, been instrumental in the early angiosperm radiation [9]. Today flies are one of the three largest and most diverse animal groups in the world [10] comprised of over 160,000 named species in about 150 families [11]. At least seventy-one families of flies comprise flower-visiting flies, and flies are pollinators of, or at least regular visitors to, at least 555 flowering plant species [12] and pollinators of more than 100 cultivated plants including such important crops as mango, cashew, tea, cacao, onions, strawberries, cauliflower, mustard, carrots, apples [13] and leek [14].

Bees are characterized by complex life histories and have specific requirements for nutrition and nesting [15]. They need rich flowering plants habitats as a large proportion of the species only collect pollen from certain plants [16-18]. In addition, bees have specific nesting sites, such as dead wood, bare soil, plant stems, or rock fissures. As bees are typical central-place foragers, which return to their nests after foraging, therefore, feeding and nesting sites must be close to one another [19]. Several studies showed that the bee populations vary widely in abundance and species composition within and between years [20-23]. Ecological patterns of bees are expected to vary during the season as in central Europe bee species have distinct phenology. Therefore, knowledge of the ecological, seasonal, and annual patterns shown by bee communities is crucial for the use of bees as bio-indicators.

Pakistan is a country where very little is known about the biodiversity of insect pollinators and their interaction with flowering plant. Insect pollinators enjoy the status of our natural resources as pollination is the most important contribution insects make to human economies and because of its yield-optimizing benefits, insects pollination can play an important role in maintaining a sustainable and profitable agriculture with minimized disruption to environment. The economic value of insect pollination goes beyond production agriculture because insects pollinate more than just crop plants. Without knowing the natural resource of our pollinators and flowering plants, we may not be able to know about endangered species and threats to our natural ecosystems. Keeping in view the economic value of pollinators and unavailability of detailed 
information from this part of the world, current study was designed to investigate seasonal variations in diversity and abundance of pollinators in relation with temperature and relative humidity.

\section{Materials and Methods}

\section{Study Site}

The study was conducted from January to December, 2010 in a planted forest of 750 hectares of Pirowal safari park, district Khanewal, Pakistan $\left(30.255^{\circ} \mathrm{N} ; 71.513^{\circ} \mathrm{E}\right.$; $114 \pm 6$ meter above sea level).A fenced wild life sanctuary along with agro forestry practices, also having a combination growing trees, herbs and shrubs with irrigated water. The climate of the area is subtropical with mean daily maximum and minimum temperatures range from 19.4 to $43.3^{\circ} \mathrm{C}$ and $5^{\circ} \mathrm{C}$ to $31.3^{\circ} \mathrm{C}$, respectively (Fig. 1 ).

\section{Floral visitor census}

Besides planted trees, a variety of natural vegetation grows in the forest including annual wild plants and perennial shrubs. We focused on the available plant species in flower during the full course of our study. As different plant species had different kinds of inflorescence types, we defined the floral units for each plant species separately and each time recorded observations from those floral units.

To determine the variations in abundance and diversity of flower visiting insects, method of
Banazak, 1980 and Fussell and Corbet, 1992 was followed, and observation was done in linear transects of 150 feet and 1 meter wide. Number of floral visitors per insect species per plant species (greater than $3 \mathrm{~mm}$ in length) will be recorded. To measure spatial variations in pollinator abundance and diversity, different isolated locations of any forested landscape category (described in objective 4) will be selected. Walks will be carried out fortnightly for one year. Three walks will be carried out each day, 8:00-9:00 am, 12:30-2:00 pm and 4:00-5:00 pm.

\section{Statistical Analysis}

The study site has all four seasons i.e. summer spring, winter and autumn, the detail of month with their temperature ranges are given in Table 1. To find out the seasonal variation of the pollinators, we compile the monthly data according to four different seasons. Then to evaluate pollinators' community assemblage in different seasons, four assemblage parameters were used i.e. Dominance, Simpson index, Shannon index and evenness index. To find out the relative abundance of pollinators' species in distant seasons we were used the rank abundance curve. Similarly these indices and rank abundance curve were used for flies, bees and wasps species.

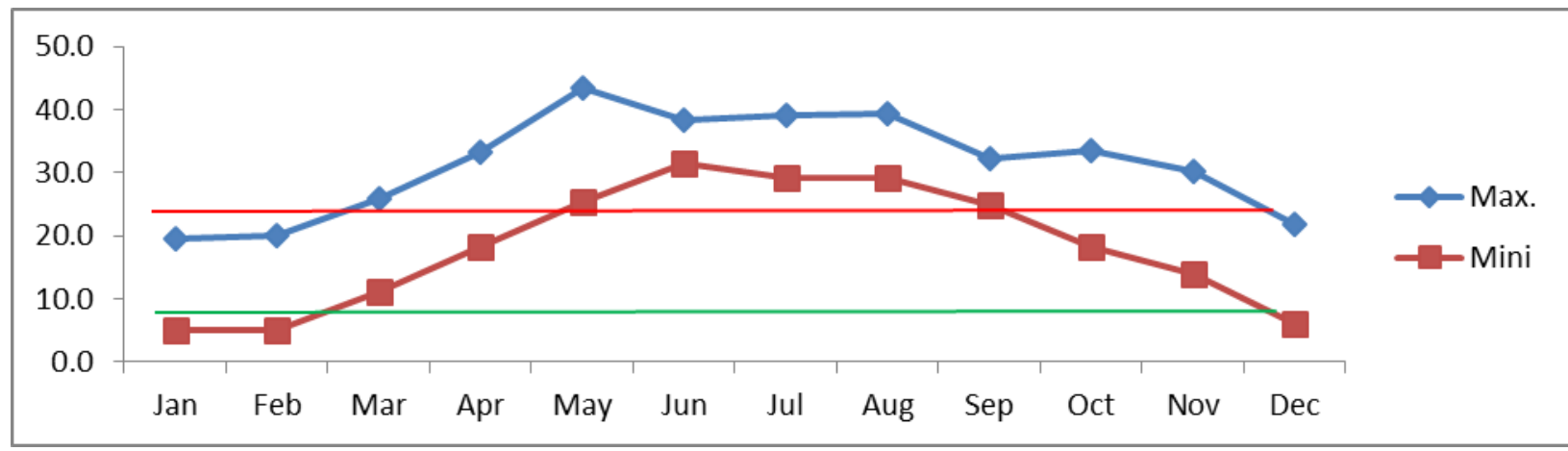

Figure 1. Month wise minimum and maximum average temperature of Pirowal (Khanewal) for the year 2010 . 
Table 1. Temperature range of different seasons in months of the year

\begin{tabular}{ccc}
\hline Seasons & Months & Temperature Max-Mini \\
\hline Summer & May, June, July \& August & $43-29{ }^{\circ} \mathrm{C}$ \\
Spring & March \& April & $30-15{ }^{\circ} \mathrm{C}$ \\
Winter & December, January \& February & $05-21{ }^{\circ} \mathrm{C}$ \\
Autumn & September, October \& November & $33-22{ }^{\circ} \mathrm{C}$ \\
\hline
\end{tabular}

\section{Results}

In total 8000 individuals belonging to 120 different species were recorded throughout the study period representing the two major flowers visiting insect orders i.e. Diptera and Hymenoptera. After analysis of the data it is clear that the maximum diversity and abundance was found in the season spring followed by summer and autumn respectively while the minimum in winter.

The hierarchical cluster analysis grouped winter and summer into one cluster while spring and autumn into another cluster on the basis of similarity in species assemblage (Fig. 2). To evaluate pollinators' community assemblage in different seasons, four assemblage parameters were used, Dominance, Simpson index, Shannon index and evenness index. The highest richness (114 species) value was observed in spring with the minimum (33) in winter (Table-2).
The highest values of Simpson and Shannon indexes were found at summer. Either winter was the lowest in Simpson and Shannon indexes but it was highest in dominance and evenness index (Table 2). The rank abundance curves of pollinators' species of summer show that there were many species with less abundance while only few species with much higher abundance. The top most abundant species included Megachilidae sp.15, Hallictidae sp6 and Apidae sp.16, similarly spring show that the top most abundant species included Crabonidae sp.4, Halictidae sp.13 and Megachilidae sp.6, while winter show that the top most abundant species included Megachilidae sp.6, Megachilidae sp.5 and Empidadae sp.1and autumn show that the top most abundant species included Crabonidae sp.4, Crabonidae sp.2 and Crabonidae sp.3. (Fig. $3)$.

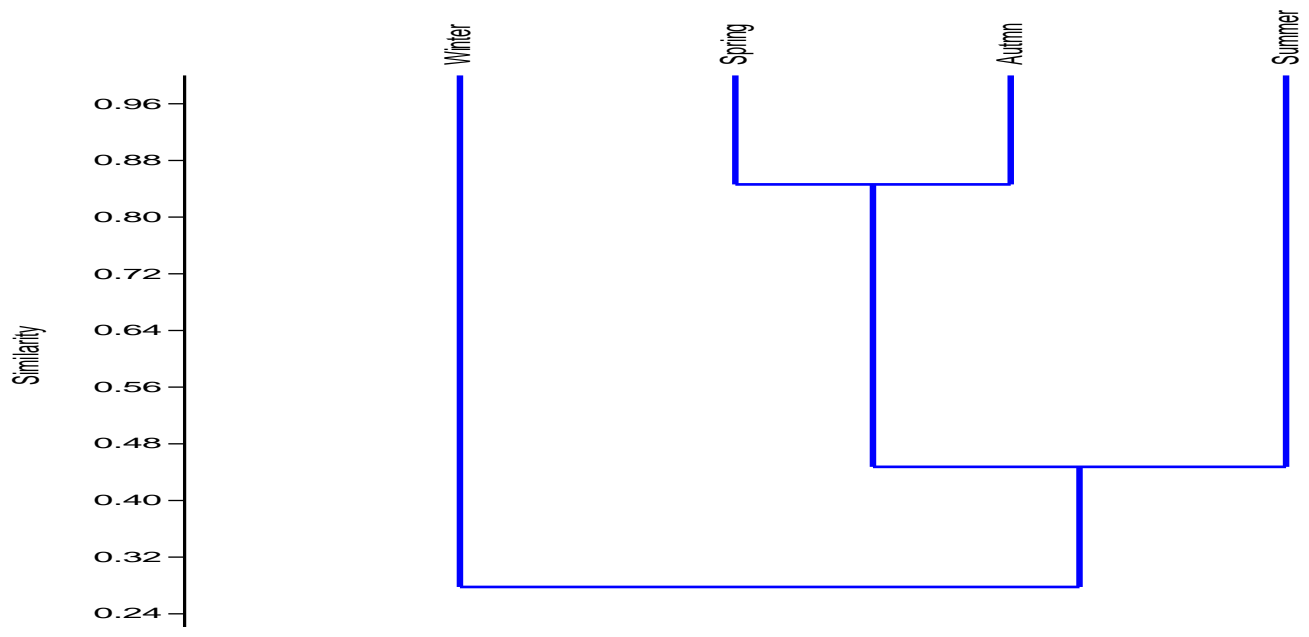

Figure 2. Hierarchical cluster analysis of four seasons based on abundance and richness of pollinator species with Jaccard similarity index . 
Table 2. Pollinators species assemblage by using different indices like Dominance, Simpson, Shanaon \& Evenness assemblage in four different seasons

\begin{tabular}{|c|c|c|c|c|}
\hline Indices & Summer & Spring & Winter & Autumn \\
\hline Abundance & 110 & 114 & 33 & 77 \\
\hline Richness & 4862 & 6770 & 938 & 1339 \\
\hline Dominance & 0.060 & 0.064 & 0.099 & 0.117 \\
\hline Simpson & 0.941 & 0.936 & 0.901 & 0.883 \\
\hline Shannon & 3.483 & 3.424 & 2.673 & 2.913 \\
\hline Evenness & 0.296 & 0.269 & 0.439 & 0.239 \\
\hline
\end{tabular}

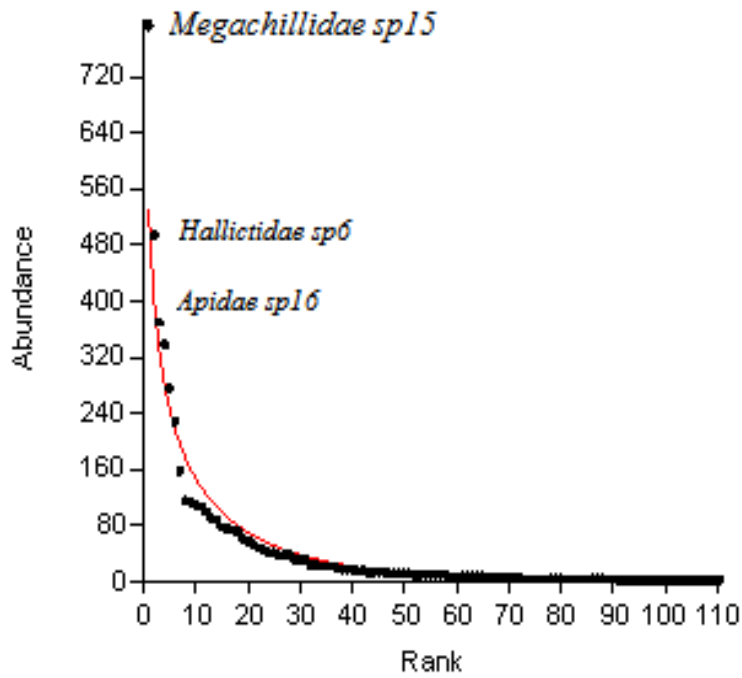

Rank Abundance Curve of Pollinators in Summer Season

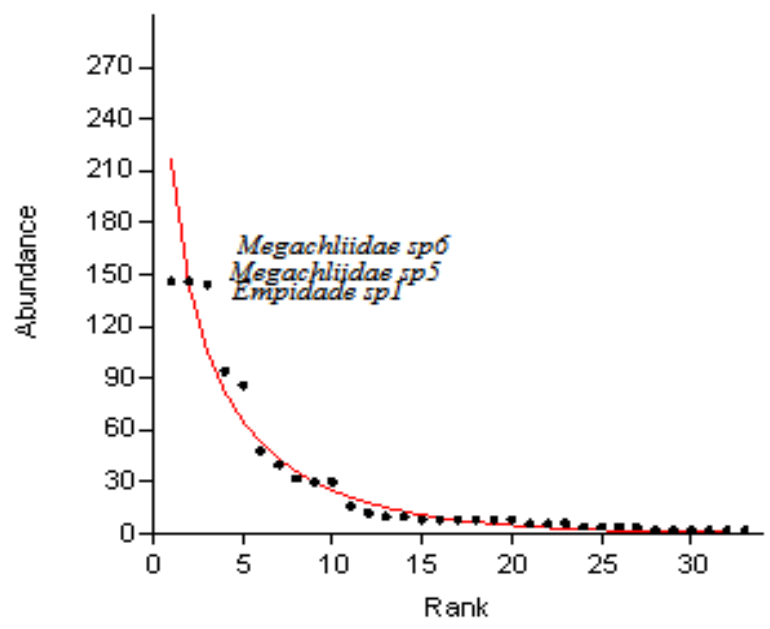

Rank Abundance Curve of Pollinators in Winter Season

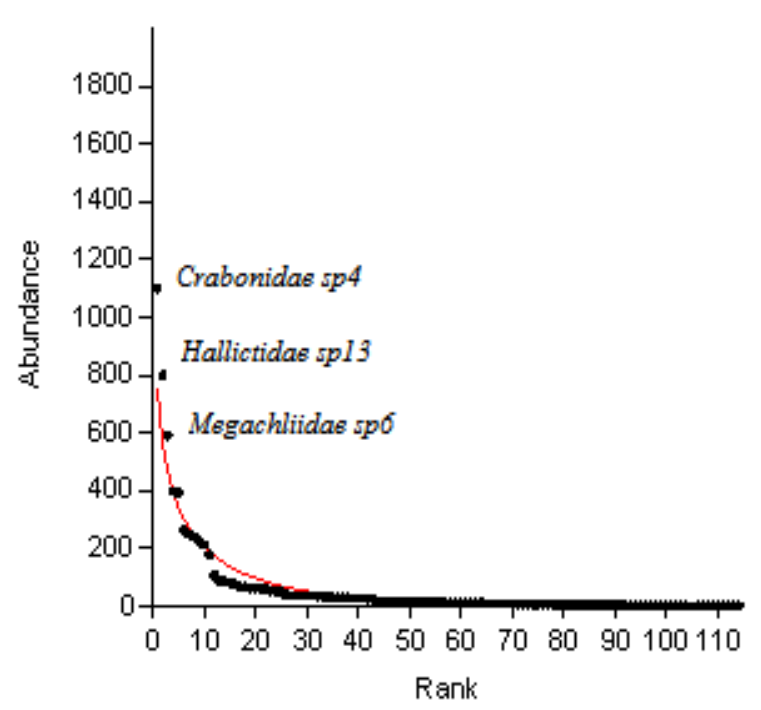

Rank Abundance Curve of Pollinators in Spring Season

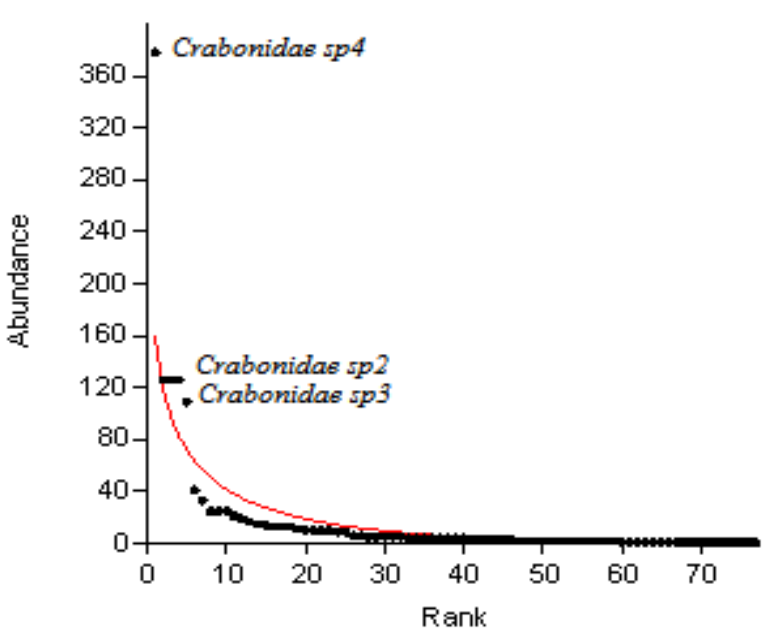

Rank Abundance Curve of Pollinators in Autumn Season

Figure 3. Rank abundance curves of pollinator (all three categories collectively) for all four seasons showing the three most abundant species in numbers. 


\section{Dipteran Diversity}

Flies remained active throughout the year but their diversity and abundance varied with the change of seasons. To evaluate fly community assemblage in different seasons, four assemblage parameters were used, Dominance, Simpson index, Shannon index and evenness index. The highest richness (28 species) value was observed in spring whiles the minimum (15) in autumn (Table 3 ). The highest value of Simpson was found in autumn and Shannon indexes were found in autumn. Either summer was the lowest in Simpson, Shannon or evenness index but it was highest in dominance. The value evenness index was the highest in autumn (Table 3).

\section{Flies Abundance}

In total 42 species of flies representing from ten different families were observed during the whole study period. The rank abundance curves of flies' species of summer show that there were many species with less abundance while only few species with much higher abundance. The top most abundant species included Domestica sp, Diptera sp.6 and Empadidae arvorum; while spring and winter show the same response and that the top most abundant species included Empadidae sp.1, Diptera sp.2 and Diptera sp.1, and autumn show that the top most abundant species included Diptera sp.1, Empadidae laetus and Bombyliidae sp.3. (Fig. 4).

\section{Bee Diversity}

Data showed that bees remained active throughout the year period, however their diversity and abundance varies with the change of temperature and humidity like as the maximum number of taxa and individuals were observed from March to May and the minimum in the month of January and December. To evaluate bees' community assemblage in different seasons, four assemblage parameters were used, Dominance, Simpson index, Shannon index and evenness index. The highest richness (40 species) value was observed in spring whiles the minimum (16) in winter (Table 4). The highest value of Simpson and Shanon was found in autumn. Either winter was the lowest in Simpson, Shannon and evenness indexes but it was highest in dominance and evenness indexes (Table 4).

\section{Bees Abundance}

In total 68 bees species representing from five different families were observed during the whole study period. The rank abundance curves of bees' species of summer show that there were many species with less abundance while only few species with much higher abundance. The top most abundant species included Pseudapis sp., Agapostemon sp. and Nomia sp., similarly spring show that the top most abundant species included Halictidae sp9, Megachaliidae sp.6 and Megachaliidae sp.5 while winter show that the top most abundant species included Megachaliidae sp.6, Megachaliidae sp.5 and Halictidae sp.9 and autumn show that the top most abundant species included Halictidae sp.9, Apidae sp.6 and Amigella sp. (Fig. 4).

\section{Wasp Diversity}

In total 57 species of wasp representing from seven different families were observed during the whole study period, and also noted that wasps remains active from the month of March to November in this ecosystem i.e. below 20 oC the activity of the wasps stopped, moreover, their diversity and abundance varies with the change of temperature and humidity, the data shows that the maximum number of taxa and individuals were observed in May (Summer) and the minimum in the month of September (Autumn) while in winter there were zero activity recorded (Ttable 5). To evaluate wasp' community assemblage in different seasons, four assemblage parameters were used, Dominance, Simpson index, Shannon index and evenness index. The highest richness (23 species) value was observed in spring whiles the minimum $(0)$ in winter 
(Table 5). The highest value of Simpson and Shanon was found in spring and autumn. Either winter was the lowest in Simpson, Shannon and evenness indexes except winter where all values were zero but it was highest in dominance and evenness indexes (Table 5).

\section{Wasps Abundance}

In total 47 wasps species representing from ten different families were observed in a year period. The rank abundance curves of wasps' species of summer show that there were many species with less abundance while only few species with much higher abundance. The top most abundant species included Vespidae sp.2,Vespidae sp.1 and Sepcidae sp., while spring and autumn show similar response regarding abundance of wasp species and the top most abundant species included Crabonidae sp.4, Crabonidae sp. 2 and Crabonidae sp.2, while in winter there was zero activity. (Fig. 5).

Table 3. Flies species assemblage by using different indices like Dominance, Simpson, Shanaon \& Evenness assemblage in four distinct Seasons

\begin{tabular}{lcccc}
\hline Indices & Summer & Spring & Winter & Autumn \\
\hline Abundance & 23 & 28 & 17 & 15 \\
Richness & 1628 & 515 & 442 & 73 \\
Dominance & 0.294 & 0.146 & 0.183 & 0.119 \\
Simpson & 0.707 & 0.854 & 0.817 & 0.881 \\
Shannon & 1.725 & 2.399 & 2.080 & 2.358 \\
Evenness & 0.244 & 0.393 & 0.471 & 0.705 \\
\hline
\end{tabular}
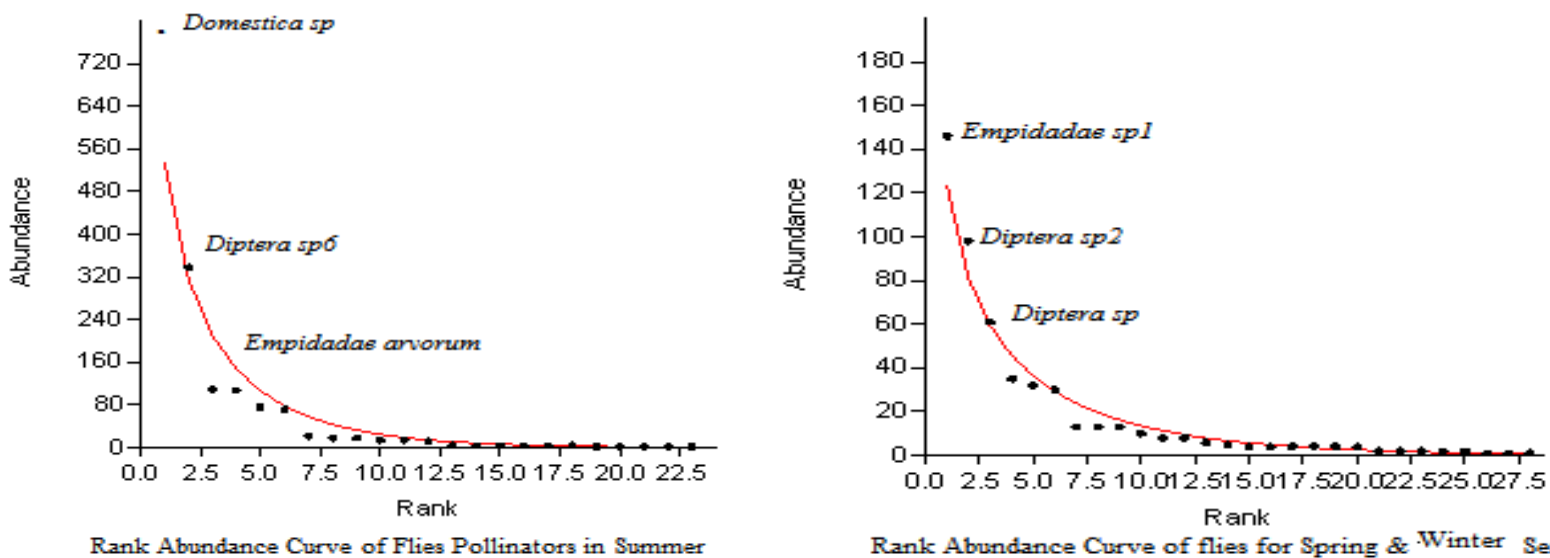

Rank Abundance Curve of Flies Pollinators in Summer

Rank Abundance Curve of flies for Spring \& Winter Seasons

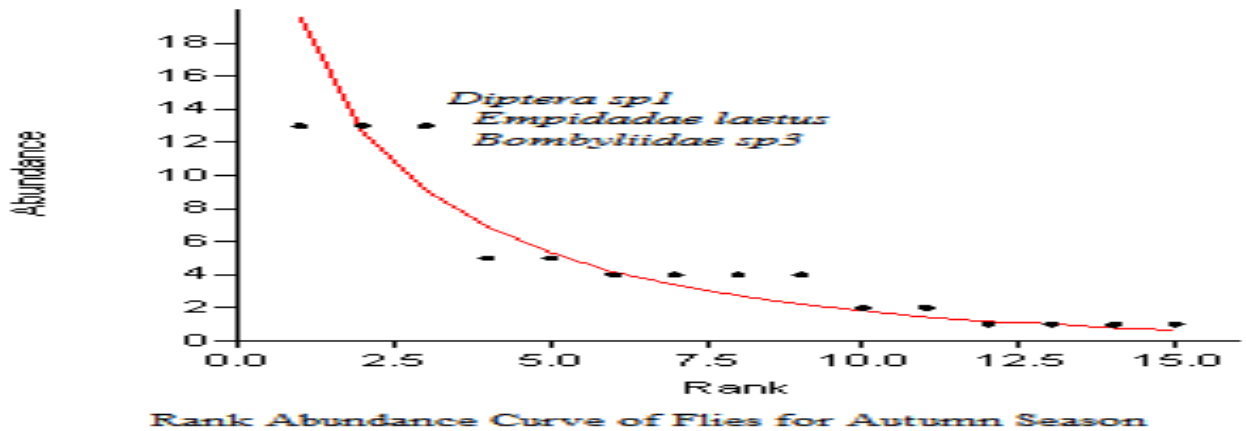

Figure 4. Rank Abundance Curves of flies Pollinators for all four seasons showing the three most abundant species among flies in numbers. 
Bashir et al.

Table 4. Bees species assemblage by using different indices like Dominance, Simpson, Shanaon \& Evenness assemblage in four distinct Seasons

\begin{tabular}{lcccc}
\hline Indices & Summer & Spring & Winter & Autumn \\
\hline Abundance & 28 & 40 & 16 & 39 \\
Richness & 1578 & 898 & 496 & 402 \\
Dominance & 0.127 & 0.127 & 0.210 & 0.108 \\
Simpson & 0.873 & 0.873 & 0.790 & 0.892 \\
Shannon & 2.426 & 2.558 & 1.894 & 2.805 \\
Evenness & 0.404 & 0.323 & 0.415 & 0.424 \\
\hline
\end{tabular}
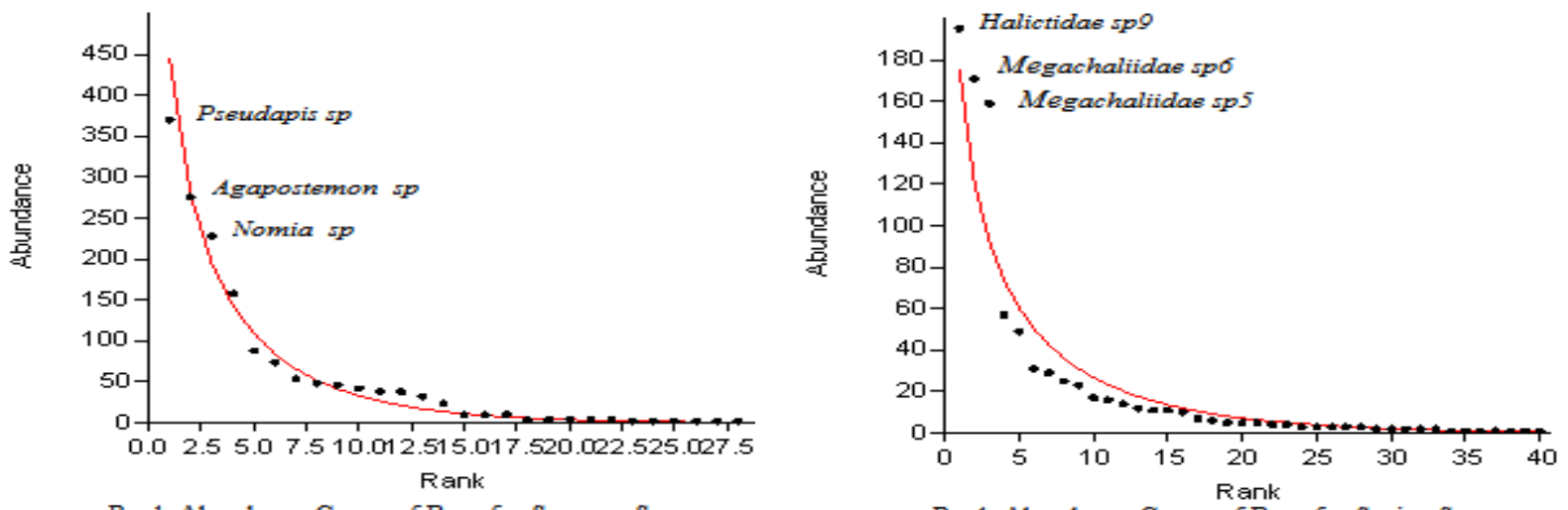

Rank Abundance Curve of Bees for Summer Season
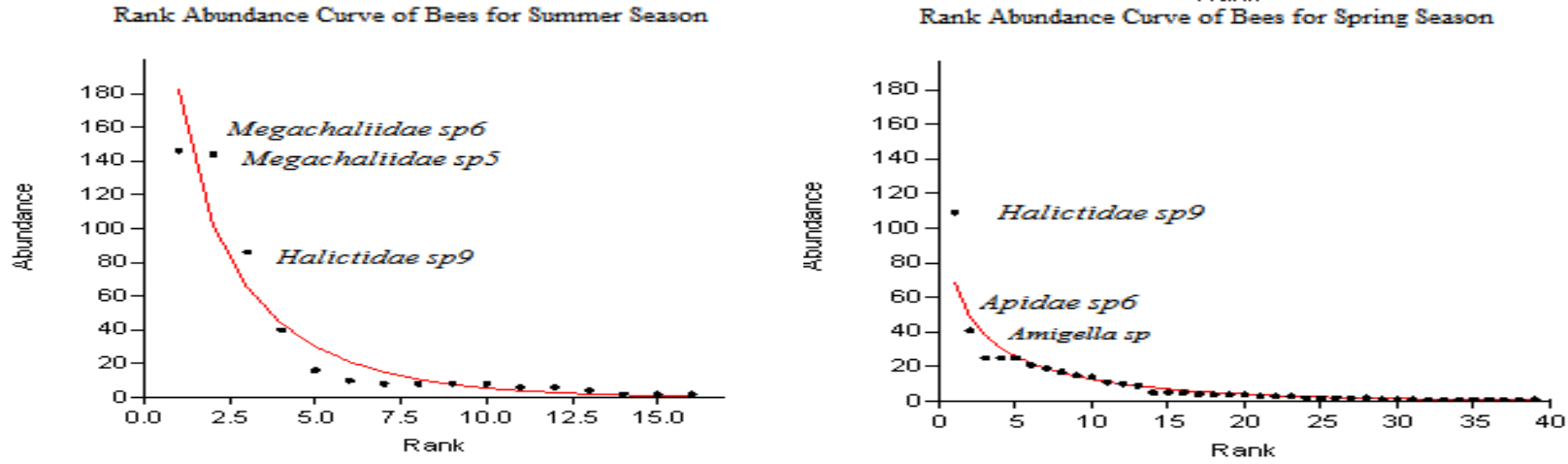

Rank Abundance Curve of Bees Pollinators for Winter Season

Rank Abundance Curve of Bees Pollinators for Autumn :

Fig. 5. Rank Abundance Curves of Bees pollinators for all four seasons showing the three most abundant species among bees in numbers 
Table-5 Wasp species assemblage by using different indices like Dominance, Simpson, Shanaon \& Evenness assemblage in four distinct Seasons

\begin{tabular}{lcccc}
\hline Indices & Summer & Spring & Winter & Autumn \\
\hline Abundance & 14 & 23 & 0 & 23 \\
Richness & 854 & 864 & 0 & 864 \\
Dominance & 0.364 & 0.257 & 0.000 & 0.257 \\
Simpson & 0.636 & 0.743 & 0.000 & 0.743 \\
Shannon & 1.560 & 1.767 & 0.000 & 1.767 \\
Evenness & 0.340 & 0.254 & 0.000 & 0.254 \\
\hline
\end{tabular}
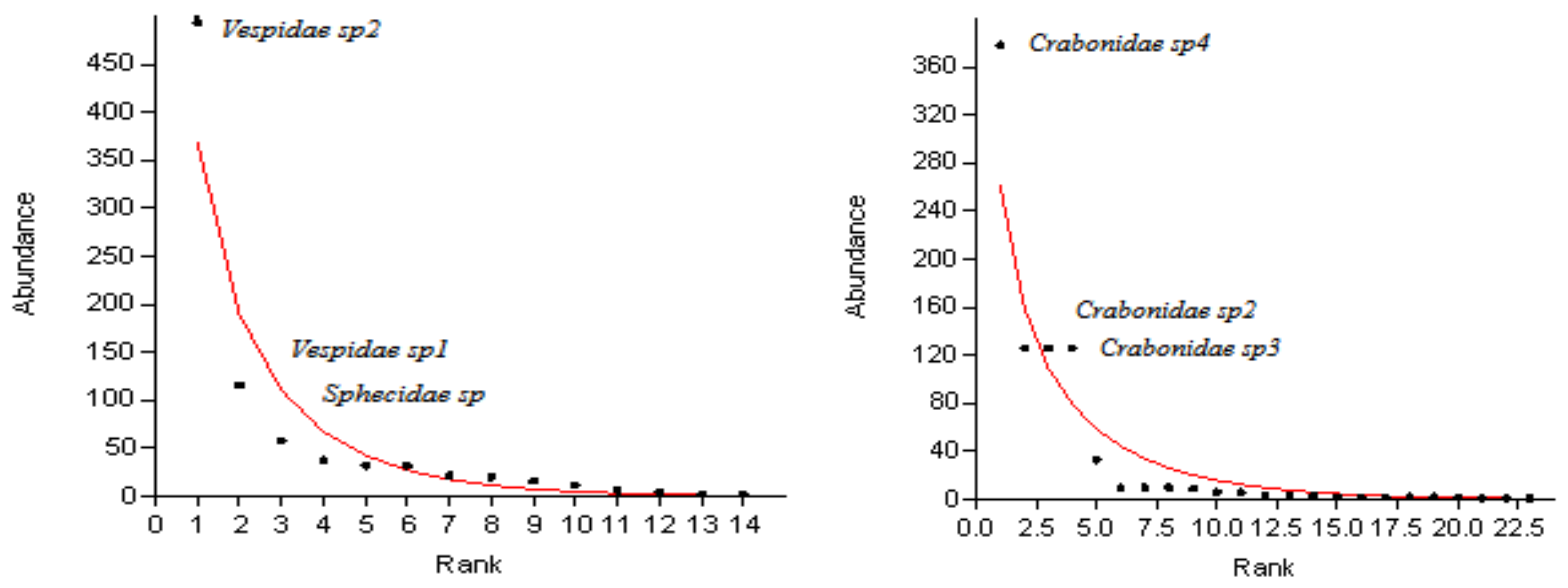

Rank Abundance Curve of Wasps Pollinators for Summer :

Rank Abundance Curve of Wasps Pollinators for Spring \& Autumn

Figure 6. Rank Abundance Curves of wasps' pollinators showing the three most abundant species among wasps in number.

\section{Discussion}

The present study showed that bees and flies remain active throughout the year i.e. with mean daily maximum and minimum temperatures range from 19.4 to $43.3^{\circ} \mathrm{C}$ and $5^{\circ} \mathrm{C}$ to $31.3^{\circ} \mathrm{C}$, respectively, while the wasps remain active above $20{ }^{\circ} \mathrm{C}$. Our results were supported with the earlier study [24-31, 2023] they resulted that pollinators populations vary widely in abundance and species composition within and between years. And also supported by A decline in pollinator population abundance and diversity has been registered worldwide. Anthropogenic alterations in climates and habitats have resulted in reductions in the biodiversity of many pollinator families [32].

The maximum diversity of flies found at temperature $250 \mathrm{C}$ to $40^{\circ} \mathrm{C}$ and from temperature $240 \mathrm{C}$ diversity goes to decline and at $100 \mathrm{C}$ diversity of flies remain at its lowest while for abundance among flies, Euphumosiasp, E.aeneus, and Muscadomesteca were most abundant and Calliphore sp. and Euphumosiatenax were the least abundant species while Euphumosia sp., E.aeneusand Musca domesteca were the species which remains active for maximum time in a year. The seasonal peak, in form of individual numbers of specie was found in August and July being at their maximum size. 
The seasonal maximum in the numbers of species in June 2001 and July might reflect the differing phenology of the bee taxa resulting in the coexistence of late spring and early summer species at this time.

Similarly for bees, the maximum diversity found at temperature $300 \mathrm{C}$ to $40^{\circ} \mathrm{C}$ and from temperature $290 \mathrm{C}$ diversity goes to decline and from below this temperature and the diversity of bees remained its lowest at 10 OC and below this temperature, while for abundance, Apis and Halictus species remained most abundant and also active throughout the year. The most numerous, in terms of number of individuals counted, was the family Apidae followed by Andrenidae and Megachilidae (Sonja et al 2012).

While for wasps the maximum diversity found at temperature ranges $250 \mathrm{C}$ to $300 \mathrm{C}$ and from temperature $240 \mathrm{C}$ diversity goes to decline and below temperature 20 0C diversity of wasps remain at its lowest while for abundance, among wasps Delta dimidiatipenne, D. esuriensesuriens and Vespa orientalis were the most abundant and wasps Chrysidinae sp.,Cercerinae sp. and Mutillinae sp. were least abundance in form of numbers of individual.

The species composition of a bee assemblage differed in different month of a year due to fluctuation of temperature; this result highlights the significance of biodiversity studies being done over two complete seasons. The evaluation of total species richness in the area suggests that only a few species remained invisible. This indicates that recording an entire bee fauna is possible by intensive collecting over two seasons. Our findings show that changes in the season have a marked effect on the ecological patterns shown by a bee grouping. Therefore, sampling over only part of a season will not only underestimate the diversity, but will also affect the parts of species in the different ecological categories. Thus, the timing, duration and frequency of sampling will significantly influence the results of ecological studies on bee communities and the conclusions drawn.

\section{References}

1. Waser NM, Chittka L, Price MV, Williams NM \& Ollerton J (1996). Generalization in pollination systems, and why it matters. Ecology 77: 1043-1060.

2. Faegri K \& van der Pijl L (1979). The principles of pollination ecology, 3rd revised edition. Oxford, Pergamon Press.

3. Fenster CB, Armbruster WS, Wilson P, Dudash MR \& Thomson JD (2004). Pollination syndromes and floral specialization. Annual Review of Ecology, Evolution, and Systematics 35: 375-403.

4. Frenzel M \& Brandl R (1998). Diversity and composition of phytophagous insect guilds on Brassicaceae. Oecologia 113:391399

5. Novotny V \& Basset Y (1998). Seasonality of sap-sucking insects (Auchenorrhyncha, Hemiptera) feeding on Ficus (Moraceae) in a lowland rain forest in New Guinea. Oecologia 115: 514-522.

6. Duelli P \& Obrist MK (1998). In search for the best correlates for local organismal biodiversity in cultivated areas. Biodivers. Conserv 7: 297-309.

7. Tscharntke T, Gathmann A \& SteffanDewenter I (1998). Bioindication using trapnesting bees and wasps and their natural enemies: community structure and interactions. J Appl Ecol 35: 708-719.

8. Steffan-DewenterI, MunzenberGU, Burger C, Thies C \& Tscharntke T (2002). Scale-dependent effects of landscape context on three pollinator guilds. Ecology 83: 14211432.

9. Endress, PK (2001). Origins of flower morphology. $J$ of Experimental Morphology 291(2): 105-115.

10. Skevington, JH and Dang PT (2002). Exploring the diversity of flies (Diptera). Biodiversity 3:1-27. 
11. Evenhuis NL, Pape T, Pont AC \& Thompson FC, eds. (2008). Biosystematic Database of World Diptera, Version 10.5. Available at: http://www.diptera.org/biosys.htm.

12. Larson BMH, Kevan PG \& AndInouye DW (2001). Flies and flowers: The taxonomic diversity of anthophiles and pollinators. Canadian Entomologist 133(4): 439-465.

13. Mitra B \& Banerjee D (2007). Fly pollinators: assessing their value in biodiversity conservation and food security in India. Rec Zool Surv India 107 (1): 33-48. 14. Kremen C, Williams NM, Aizen MA, Gemmill-Herren B, LeBuhn G, Minckley R, Packer L, Potts SG, Roulston T, SteffanDewenter I, Vazquez DP, Winfree R, Adams L, Crone EE, Greenleaf SS, Keitt TH, Klein A-M, Regetz J \& Ricketts TH (2007). Pollination and otherecosystem services produced by mobile organisms: a conceptualframework for the effects of landuse change. Ecology Letters 10, 299-314.

15. Westrich P (1990). Die Wildbienen Baden-Württembergs. Vol. 2. Stuttgart: Eugen Ulmer GmbH.

16. Westrich P (1990). Die Wildbienen Baden-Württembergs. Ulmer, Stuttgart, 972 pp.

17.Muller A (1996).Host-plant specialization in western palearcticanthidiine bees (Hymenoptera: Apoidea: Megachilidae). Ecol Monogr 66: 235-257.

18. Wcislo WT \& Cane JH (1996). Floral resource utilization by solitary bees (Hymenoptera: Apoidea) and exploitation of their stored food by natural enemies. Annu Rev Entomol 41:257-286.

19. Westrich P (1996). Habitat requirements of central European bees and the problems of partial habitats. In Matheson A, Buchmann SL, O'Toole C, Westrich P \& Williams IH (eds): The Conservation of Bees. Academic Press, London, pp. 1-16.
20. Banaszak J \& Cierzniak T (1997). Spatial and temporal changes in diversity and density of bees (Apidea) in the deciduous forests of Poland. In Kipyatkov V.E. (ed.): Proceedings of the International Colloquia on Social Insects. Socium, St. Petersburg, pp. 89-99. 21. Minckley RL, Cane JH, Kervin L \& Roulston TH (1999). Spatial predictability and resource specialization of bees(Hymenoptera: Apoidea) at a superabundant, widespread resource. Biol J Linn Soc 67: 119-147.

22. Roubik DW (2001). Ups and downs in pollinator populations: When is there a decline? Conserv. Ecol. 5: [online] URL: http://www.ecologyandsociety.org/vol5/iss1/ art2/.

23. Banaszak J \& Wendzonka J(2002). Bees (Hymenoptera: Apoidea) of the BoryTucholskie National Park (NW Poland). Pol J Entomol 71: 327-350.

24. Tepedino VJ \& Stanton NL (1981). Diversity and competition in bee-plant communities on short-grass prairie. Oikos 36 : 35-44.

25. Pearson DL \& Dressler RL (1985). Twoyear study of male orchid bee (Hymenoptera: Apidae: Euglossini) attraction to chemical baits in lowland south-eastern Perú. J Trop Ecol 1: 37-54.

26. Wolda H \& Roubik DW (1986). Nocturnal bee abundance and seasonal bee activity in a Panamanian forest. Ecology 67: 426-433.

27. Ortiz-Sánchez FJ \& Aguirre-Segura A(1991). Estructura y dinamicaestacional de unacomunidad de apoidea (Hymenoptera) enAlmería. Eos 67: 3-22.

28. Banaszak J \& Cierzniak T (1994). Estimate density and diversity of Apoidea (Hymenoptera) in steppe reserve "ZboczaPlutowskie" on lower Vistula River. Pol Pis Entomol 63: 319-337.

29. Ortiz-Sánchez FJ \& Belda J (1994). Fenología de unacomunidad de Apoidea (Hymenoptera) enmegioagrícolaen el sureste 
de Espaa. Bol Sanid Veget Plagas 20: 725735 .

30. Schmid-Egger C (1995). Die Eignung von Stechimmen (Hymenoptera: Aculeata) zurnaturschutzfachlichenBewertung am Beispiel der Weinbergs lands chaftim Enztal und im Stromberg (nordwestliches BadenWürttemberg). CuvillierVerlag, Göttingen, $235 \mathrm{pp}$.

31. Banaszak J \& Krzysztofiak A (1996). The natural wild bee resources (Hymenoptera:
Apoidea) of the Wigry National Park. Pol J Entomol 65: 33-50.

32. Biesmeijer JC, Roberts SPM, Reemer M, Ohlemuller R, Eswards M, Peeters T, Schaffers AP, Potts SG, Kleukers MR, Thomas CD \& Settele Jand WEKunin (2006). Paralleldeclines in pollinators and insect-pollinated plants in Britain and the Netherlands. Sci 313, 351-354. 